\title{
IMPLEMENTASI PEMBELAJARAN DENGAN METODE MOORE TERMODIFIKASI UNTUK MENINGKATKAN KEMAMPUAN PEMBUKTIAN MATEMATIK MAHASISWA
}

\author{
Abdul Aziz Saefudin \\ Universitas PGRI Yogyakarta \\ Email: aziz@upy.ac.id
}

\begin{abstract}
This research aims to describe the improvement of student's mathematical proving ability applying modified Moore method and conventional learning model in the subject of Algebra Structure. This research is a quasi-experimental research design using a nonequivalent control group design and used purposive sampling is as much as 41 students. The technique of collecting data used the mathematical proving ability test. Data were analyzed using two-step statistical descriptive and inferential statistical analysis. The research findings show that: 1) the mathematical proving ability of students who applying the Moore modified method significantly better than that students of applying the conventional learning model. 2) the improvement of the mathematical proving ability student that applying the Moore modified method of learning with a significantly better and more evenly than that students applying the conventional learning model. Based on these research, it can be recommended that learning algebra structure with modified Moore method can as an alternative method of learning to improve the mathematical proving ability.
\end{abstract}

Keywords: mathematical proving ability, modified moore method

\section{PENDAHULUAN}

Pendidikan merupakan salah satu sarana yang digunakan oleh manusia untuk hidup menjadi lebih baik di masa sekarang dan masa yang akan datang. Salah satu kecakapan hidup (life skill) yang perlu dikembangkan dalam pendidikan adalah keterampilan berpikir, terutama dalam pemecahan masalah matematika (Saefudin, 2012). Hal ini diperlukan agar mahasiswa kelak dapat menggunakan keterampilan berpikir tersebut menjadi salah satu sarana untuk memecahkan berbagai permasalahan yang dihadapi dalam kehidupan nyata.

Ketrampilan berpikir matematik perlu dimiliki mahasiswa karena konsep-konsep matematika tersusun secara hierarkis, terstruktur, logis, dan sistematis mulai dari konsep yang paling sederhana sampai pada konsep yang paling kompleks. Ketrampilan ini penting karena materi matematika semakin sulit untuk dipelajari di tingkat perguruan tinggi. Artigue (1998) dan Cornu (1991) (dalam Suryana, 2012) mengemukakan bahwa pembelajaran matematika sering dinilai negatif oleh mahasiswa dan mereka memiliki kesulitan yang cukup besar terhadap beberapa proses matematika seperti penalaran, pemecahan masalah yang tidak rutin, dan membuktikan.

Sejalan dengan hal itu, Tall (2002) menyatakan bahwa perubahan dari berpikir elementer ke berpikir matematis tingkat lanjut melibatkan suatu transisi yang signifikan, yaitu dari mendeskripsikan ke mendefinisikan, dari meyakinkan ke membuktikan secara logika berdasarkan pada suatu definisi. Bagi mahasiswa, proses peralihan tersebut menjadi suatu 
permasalahan tersendiri. Salah satu penyebabnya adalah pada saat di sekolah, matematika yang mereka pelajari meliputi kombinasi dari representasi visual, termasuk geometri dan grafik, perhitungan dan manipulasi simbolis, sedangkan matematika di perguruan tinggi lebih menekankan pada kerangka formal sistem aksiomatik dan bukti matematika. Oleh karena itu, mahasiswa membutuhkan kemampuan berpikir yang berbeda dibandingkan saat masih di sekolah. Kemampuan berpikir yang dimaksud adalah kemampuan berpikir matematika tingkat lanjut (advance mathematical thinking). Sumarmo (dalam Suryana, 2012) mengemukakan bahwa kemampuan berpikir matematika tingkat lanjut adalah kemampuan berpikir yang meliputi representasi, abstraksi, menghubungkan representasi dan abstraksi, berpikir kreatif matematis, dan membuktikan matematis. Salah satu aspek kemampuan berpikir tingkat lanjut yang dikaji dalam penelitian ini adalah kemampuan pembuktian matematik mahasiswa.

Struktur Aljabar merupakan salah satu mata kuliah yang diberikan bagi mahasiswa Program Studi (Prodi) Matematika dan Pendidikan Matematika di Indonesia. Mata kuliah ini baanyak memuat konsep-konsep yang abstrak dan teorema-teorema yang perlu dibuktikan sehingga Struktur Aljabar dikenal sebagai mata kuliah yang sulit (Nurlaelah, 2009). Oleh karena itu, dosen perlu memberikan pembelajaran yang kreatif dan bermakna bagi mahasiswa agar mahasiswa mudah memahami konsepnya. Meskipun begitu, pada umumnya, pembelajaran Struktur Aljabar saat ini masih cenderung berlangsung satu arah, yaitu dari dosen ke mahasiswa. Pola pembelajaran pada setiap pertemuan yang diterapkan oleh dosen adalah: menjelaskan definisi atau teorema, memberikan contoh-contoh yang berkaitan dengan definisi atau membuktikan teorema, memberikan latihan, dan di akhir pembelajaran dosen memberikan tugas (PR), pola pembelajaran seperti ini disebut pola pembelajaran konvensional (Maya dan Sumarmo, 2009).

$\begin{array}{ccr}\text { Pada } & \text { pembelajaran } & \text { secara } \\ \text { konvensional, } & \text { mahasiswa } & \text { pada }\end{array}$ umumnya bersikap pasif selama pembelajaran (mereka kurang berani untuk mengkomunikasikan gagasangagasan yang mereka miliki), dosen mendominasi kegiatan kelas, pembelajaran terpusat pada dosen, dan orientasi dosen lebih banyak tercurah pada target tercapainya materi perkuliahan. Dengan metode pembelajaran seperti ini, pembelajaran yang dilaksanakan kurang bermakna, dan tidak jarang suatu konsep hanya dipahami sebagai hafalan (bukan sebagai pengertian). Akibatnya, konsep tersebut mudah dilupakan dan bahkan sering suatu konsep matematika dipahami secara keliru oleh mahasiswa. Semua ini pada akhirnya menyebabkan mahasiswa tidak dapat menerapkan dengan baik konsep-konsep yang telah dipelajarinya dalam menyelesaikan soal-soal latihan (Arnawa, dkk, 2009).

Pembelajaran Struktur Aljabar yang demikian mengakibatkan kemampuan berpikir tingkat lanjut, terutama kemampuan membuktikan masih lemah. Maya dan Sumarmo (2009) menyebutkan bahwa kesulitan mahasiswa dalam membuktikan, sebagian besar disebabkan karena mereka tidak dapat melihat lebih jauh tentang pernyataan-pernyataan matematik (teorema), bukan karena mereka tidak memahami pernyataanpernyataan yang terlibat. Hal ini juga diperkuat pendapat Herlina (2013; 
2015) yang menyatakan bahwa pembuktian matematis merupakan fase yang sulit bagi mahasiswa. Hal ini disebabkan oleh beberapa hal, di antaranya mahasiswa tidak memahami suatu definisi dan teorema dengan baik, fakta ini terlihat dari tidak mampunya mahasiswa merepresentasikan definisi tersebut. Selain itu, Moore (Maya dan Sumarmo, 2009) menyakini bahwa mahasiswa tidak terlibat aktif dalam proses pembuktian. Lebih lanjut diungkap oleh Moore bahwa mahasiswa hanya akan mendapatkan sedikit pelajaran tentang matematika lanjut (advanced mathematics), bila mereka secara pasif hanya menulis bukti yang diberikan oleh pengajarnya di papan tulis, sementara mahasiswa akan banyak belajar tentang konsep matematik dan bukti apabila mereka mencoba mengkonstruksi bukti sendiri.

Apakah sebenarnya bukti (proof) itu? Kamus Collins Cobuild, "Proof is evidence or fact that show that it is true or that it exists". Sementara membuktikan (to prove) bahwa sesuatu itu benar berarti menunjukkan dengan pasti bahwa itu betul atau benar, sebagaimana dinyatakan dalam kamus yang sama, "To prove that something is true or corrrect means to show definitely that it is true or correct" (Maya dan Sumarmo, 2009). Sementara Hanna (dalam Yoo, 2008) menyatakan bahwa bukti merupakan representasi dari hasil matematika untuk mengkomunikasikan pemahaman kepada komunitas matematika lainnya dan menerimanya sebagai teorema baru.

Sumarmo (dalam Suryana, 2013), terdapat dua kemampuan dalam pembuktian matematis, yaitu: 1) kemampuan membaca bukti, yaitu kemampuan menemukan kebenaran dan/atau kesalahan dari suatu pembuktian serta kemampuan memberikan alasan setiap langkah pembuktian; dan 2) kemampuan mengkonstruksi bukti, yaitu kemampuan menyusun suatu bukti pernyataan matematika berdasarkan definisi, prinsip, dan teorema serta menuliskannya dalam bentuk pembuktian lengkap (pembuktian langsung atau tak langsung).

Kesulitan mahasiswa dalam membuktikan dapat diatasi, salah satunya dengan meningkatkan kemampuan pemahaman matematik mereka. Pemahaman konsep matematika yang baik akan memudahkan mereka dalam memahami bukti dan melakukan pembuktian dengan baik. Dengan kata lain, kemampuan pembuktian matematik mahasiswa menjadi berkembang.

Untuk mengembangkan kemampuan pembuktian tersebut, perlu diupayakan suatu pembelajaran yang memberi kesempatan kepada siswa untuk berpikir mandiri dan terlibat aktif dalam pembelajaran. Salah satu pembelajaran yang dapat dikembangkan adalah pembelajaran dengan metode Moore termodifikasi (Maya dan Sumarmo, 2009).

Metode Moore termodifikasi merupakan modifikasi dari metode Moore yang dikembangkan oleh R.L. Moore di University of Pennsylvania pada tahun 1911-1916, dan diajarkan di University of Texas dari tahun 1916 sampai pensiunnya pada tahun 1969 (Mahavier, May, \& Parker, 2006). Pembelajaran dengan metode Moore termodifikasi merupakan pembelajaran yang memberikan kesempatan kepada siswa untuk secara aktif terlibat dalam pembelajaran (pembelajaran dengan pendekatan tidak langsung), di mana guru atau pengajar hanya berperan sebagai motivator, fasilitator, yang mengarahkan siswanya untuk memahami suatu konsep secara mandiri dan sedikit bantuan dari pengajar 
sehingga pemahaman dan pembuktian matematik siswa dapat berkembang lebih baik.

Menurut Mahavier, May \& Parker (2006), terdapat tiga aturan yang perlu diterapkan dalam pembelajaran dengan metode Moore termodifikasi. Aturan pertama, mahasiswa tidak diperkenankan menggunakan buku teks selama proses pembelajaran. Namun syarat pertama ini bisa ditawar, dalam arti apabila keadaan memaksa, maka mahasiswa dapat melihat buku teks atas seijin pengajar. Aturan kedua, pembelajaran dilakukan dalam kelas kecil (kurang dari 24 siswa). Aturan ketiga adalah tidak boleh ada kolaborasi di antara mahasiswa.

Berdasarkan berbagai uraian tersebut, tujuan dalam penelitian ini adalah sebagai berikut: 1) untuk mengetahui deskripsi kemampuan pembuktian matematik mahasiswa yang mengikuti pembelajaran dengan metode Moore termodifikasi dan mahasiswa yang mengikuti pembelajaran konvensional dalam perkuliahan Struktur Aljabar, 2) untuk mengetahui peningkatan kemampuan pembuktian matematik mahasiswa yang mengikuti pembelajaran dengan metode Moore termodifikasi lebih baik daripada mahasiswa yang mengikuti pembelajaran konvensional dalam perkuliahan Struktur Aljabar.

\section{METODE PENELITIAN}

Penelitian ini merupakan penelitian eksperimen semu (quasi experiment) dengan rancangan nonequivalent control group design (Sugiyono, 2011: 118). Populasi penelitian yakni seluruh mahasiswa yang mengambil mata kuliah Struktur Aljabar sebanyak 78 orang. Pengambilan sampel dilakukan dengan menggunakan teknik sampel bertujuan (purposive sampling) yaitu 41 orang mahasiswa yang terdapat dalam dua kelas dengan satu kelas sebagai kelas eksperimen dan satu kelas sebagai kelas kontrol. Instrumen yang digunakan adalah instrumen tes kemampuan pembuktian matematik mahasiswa dalam menyelesaikan soal mata kuliah Struktur Aljabar yang telah diuji validitas dan reliabilitasnya.

Hasil validasi isi intrumen tes kemampuan pembuktian matematik menunjukkan bahwa seluruh butir dinyatakan valid oleh validator dan layak digunakan. Sementara validitas butir tes yang diukur dengan menggunakan rumus product moment menunjukkan bahwa seluruh butir dinyatakan valid $\left(\mathrm{r}_{x y}>0,3\right)$. Reliabilitas instrumen tes kemampuan pembuktian matematik dilakukan dengan menggunakan rumus Alpha Cronbach. Hasil analisisnya menunjukkan bahwa reliabilitas tes kemampuan pembuktian matematik $\left(\mathrm{r}_{11}\right)$ adalah 0,72 . Oleh karena $0,72>0,7$ maka instrumen tes kemampuan pembuktian matematik adalah reliabel. Analisis data penelitian dilakukan melalui dua tahap, yaitu analisis statistik deskriptif dan analisis statistik inferensial. Uji hipotesis dianalisis menggunakan uji $t$ independen pada skor gain ternormalisasi.

\section{HASIL PENELITIAN DAN PEMBAHASAN \\ Deskripsi Hasil Penelitian}

Pada tahap awal yang dilakukan pada kedua kelompok sampel yakni kelas eksperimen dan kelas kontrol adalah memberikan pretest. Setelah itu, dilakukan pembelajaran dengan metode Moore termodifikasi di kelas eksperimen dan pembelajaran di kelas kontrol. Di akhir pertemuan, kedua kelas diberikan posttest kemampuan pembuktian matematik. Hasil pretest dan posttest kemampuan pembuktian 
ISSN 2089-8703 (Print) Vol. 6, No. 3 (2017)

ISSN 2442-5419 (Online)

matematik mahasiswa adalah sebagai berikut.

Tabel 1. Deskripsi Hasil Pretest dan Posttest Kemampuan Pembuktian Matematik Mahasiswa Kelas Eksperimen dan Kelas Kontrol

\begin{tabular}{|l|c|c|c|c|c|c|c|}
\hline & N & \multicolumn{2}{|c|}{ Skor } & Rerata & Persentase & $\begin{array}{c}\text { Std. } \\
\text { Deviasi }\end{array}$ & Kualifikasi \\
\cline { 3 - 8 } & Min & Maks & & 5,17 & 1,28 & Sedang \\
\hline $\begin{array}{l}\text { Pretest Kelas } \\
\text { Eksperimen }\end{array}$ & 15 & 2 & 6 & 4,27 & 54,17 \\
\hline $\begin{array}{l}\text { Pretes Kelas } \\
\text { Kontrol }\end{array}$ & 26 & 2 & 6 & 3,62 & 45,19 & 1,29 & Sedang \\
\hline $\begin{array}{l}\text { Posttest Kelas } \\
\text { Eksperimen }\end{array}$ & 15 & 4 & 8 & 6,87 & 85,83 & 1,46 & Tinggi \\
\hline $\begin{array}{l}\text { Posttest Kelas } \\
\text { Kontrol }\end{array}$ & 26 & 3 & 8 & 5,65 & 70,19 & 1,74 & Tinggi \\
\hline
\end{tabular}

Catatan: $\mathrm{N}=$ banyak data; Skor maks ideal $=8$

Berdasarkan Tabel 1, dapat dideskripsikan bahwa rerata skor pretes kemampuan pembuktian matematik mahasiswa kelas eksperimen adalah 4,27 dari skor ideal 8 atau $54,17 \%$ (berkualifikasi sedang) dengan standar deviasi 1,28. Setelah kelas eksperimen diberikan pembelajaran dengan metode Moore termodifikasi, rerata skornya menjadi 6,87 dari skor ideal 8 atau $85,83 \%$ (berkualifikasi tinggi) dengan standar deviasi 1,48. Artinya, rerata skor kemampuan pembuktian matematik mahasiswa pada kelas eksperimen meningkat setelah menggunakan pembelajaran dengan metode Moore termodifikasi.

Sementara itu, deskripsi rerata skor postest kemampuan pembuktian matematik mahasiswa kelas kontrol adalah 3,62 dari skor ideal 8 atau $45,19 \%$ (berkualifikasi sedang) dengan standar deviasi 1,29. Setelah kelas kontrol menggunakan pembelajaran konvensional, rerata skornya menjadi 5,65 dari skor ideal 8 atau 70,19\% (berkualifikasi tinggi) dengan standar deviasi 1,74. Artinya, rerata skor kemampuan pembuktian matematik mahasiswa pada kelas kontrol meningkat setelah menggunakan pembelajaran konvensional.

Untuk mengetahui skor peningkatan kemampuan pembuktian matematik mahasiswa sebelum dan sesudah kegiatan pembelajaran, langkah berikutnya adalah menghitung skor gain ternormalisasi dari data pretest dan posttest kemampuan pembuktian matematik.

Tabel 2. Deskripsi Skor Gain Ternormalisasi Peningkatan Kemampuan Pembuktian Matematik Mahasiswa Kelas Eksperimen dan Kelas Kontrol

\begin{tabular}{|l|c|c|c|c|c|c|}
\hline & \multirow{2}{*}{$\mathbf{N}$} & \multicolumn{2}{|c|}{ Skor } & \multirow{2}{*}{ Rerata } & $\begin{array}{c}\text { Std. } \\
\text { Deviasi }\end{array}$ & \multirow{2}{*}{ Kualifikasi } \\
\cline { 3 - 7 } & & Min & Maks & & & \\
\hline Gain Ternormalisasi Kelas Eksperimen & 15 & 0,33 & 1 & 0,76 & 0,27 & Tinggi \\
\hline Gain Ternormalisasi Kelas Kontrol & 26 & 0 & 1 & 0,46 & 0,38 & Sedang \\
\hline
\end{tabular}

Catatan: $\mathrm{N}=$ banyak data, Skor Ideal = 1 
Berdasarkan Tabel 2, dapat dikemukakan deskripsi rerata skor gain ternormalisasi peningkatan kemampuan pembuktian matematik mahasiswa pada kelas eksperimen yang menggunakan pembelajaran dengan metode Moore termodifikasi adalah 0,76 (berkualifikasi tinggi) dan standar deviasi 0,27 , sedangkan pada kelas kontrol yang menggunakan pembelajaran konvensional adalah 0,46 (berkualifikasi sedang) dan standar deviasi 0,38. Perbandingan rerata skor gain ternormalisasi peningkatan kemampuan pembuktian matematik mahasiswa secara keseluruhan antara pembelajaran dengan metode Moore termodifikasi dengan pembelajaran konvensional adalah $0,76>0,46$; standar deviasi $0,27<0,38$. Hal ini menunjukkan bahwa peningkatan kemampuan pembuktian matematik mahasiswa yang menggunakan pembelajaran dengan metode Moore termodifikasi lebih baik daripada peningkatan kemampuan pembuktian matematik mahasiswa yang menggunakan pembelajaran konvensional.

Secara garis besar, perbandingan rerata skor pretest, skor posttest, dan skor gain ternormalisasi kemampuan pembuktian matematik mahasiswa yang mengikuti pembelajaran dengan metode Moore termodifikasi dan pembelajaran konvensional dapat dilihat pada grafik berikut.

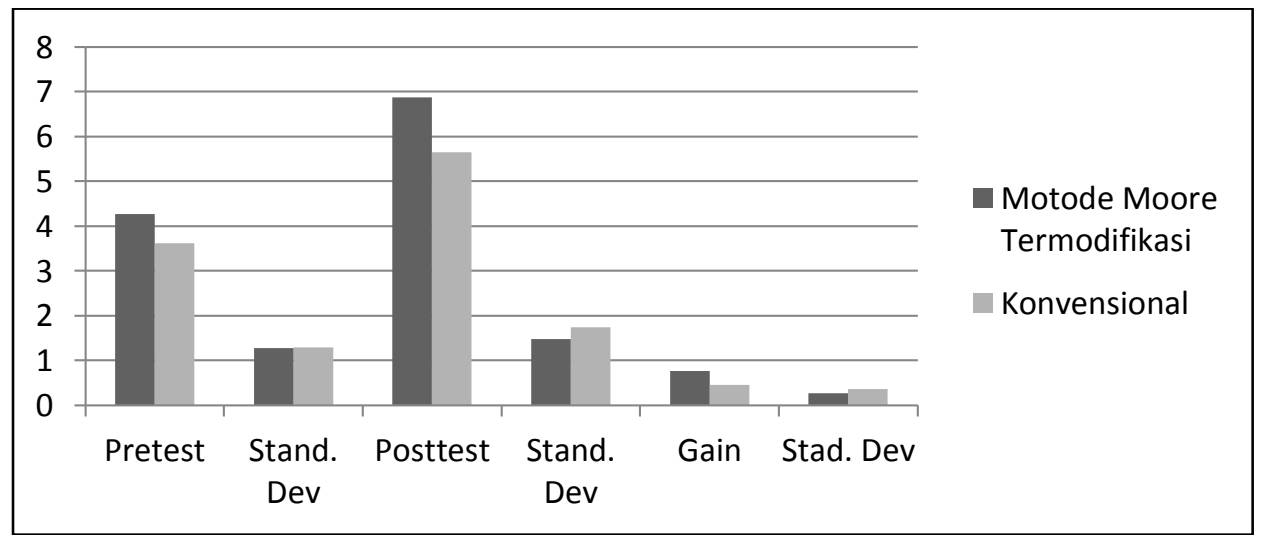

Gambar 2. Perbandingan rerata skor pretest, skor posttest, dan skor gain ternormalisasi kemampuan pembuktian matematik mahasiswa

\section{Analisis Data Penelitian Uji Prasyarat}

Uji normalitas dilakukan dengan menggunakan uji statistik KolmogorovSmirnov karena data $\leq 30$. Berdasarkan hasil uji data pretest kelas eksperimen dengan Kolmogorov-Smirnov statistik 0,25 dengan $\mathrm{df}=15$ dan signifikansi $(p)$ $=0,012<0,05$ (data tidak berdistribusi normal) dan kelas kontrol statistik 0,259 dengan $\mathrm{df}=26$ dan signifikansi $(p)=$ $0,000<0,05$ (data tidak berdistribusi normal). Nilai signifikansi pretest kelas eksperimen dan kelas kontrol menunjukkan bahwa data berasal dari populasi yang tidak berdistribusi normal karena nilai signifikansi kedua kelas kurang dari $0,05(<0,05)$.

Uji normalitas data posttest kelas eksperimen dengan KolmogorovSmirnov statistik 0,315 dengan $\mathrm{df}=15$ dan signifikansi $(p)=0,000<0,05$ (data tidak berdistribusi normal) dan kelas kontrol statistik 0,156 dengan $\mathrm{df}=26$ dan signifikansi $(p)=0,106>0,05$ (data berdistribusi normal). Nilai signifikansi 
posttest kelas eksperimen menunjukkan bahwa data berasal dari populasi yang tidak berdistribusi normal karena nilai signifikansi kurang dari 0,05 $(<0,05)$, sedangkan kelas kontrol menunjukkan bahwa data berasal dari populasi yang berdistribusi normal karena nilai signifikansi lebih dari 0,05 (>0,05).

Uji normalitas skor gain ternormalisasi kelas eksperimen dengan Kolmogorov-Smirnov statistik 0,338 dengan $\mathrm{df}=15$ dan signifikansi $(p)=$ $0,000<0,05$ (data tidak berdistribusi normal) dan kelas kontrol statistik 0,153 dengan $\mathrm{df}=26$ dan signifikansi $(p)=$ $0,119>0,05$ (data berdistribusi normal). Nilai signifikansi skor gain ternormalisasi kelas eksperimen menunjukkan bahwa data berasal dari populasi yang tidak berdistribusi normal karena nilai signifikansi kurang dari $0,000(<0,05)$, sedangkan kelas kontrol menunjukkan bahwa data berasal dari populasi yang berdistribusi normal karena nilai signifikansi lebih dari 0,05 $(>0,05)$.

Uji homogenitas digunakan untuk memperlihatkan bahwa dua kelompok data sampel berasal dari populasi yang memiliki variansi sama. Uji homogenitas dalam penelitian ini menggunakan taraf signifikansi 0,05 (5\%). Uji homogenitas pretest kelas eksperimen dan kelas kontrol dengan uji-F (Levene's test) diperoleh hasil signifikansi kemampuan pembuktian matematik mahasiswa sebesar 0,45 dengan signifikansi $(p)=0,834>0,05$ (homogen). Uji homogenitas postest kelas eksperimen dan kontrol kemampuan pembuktian matematik mahasiswa sebesar 0,776 dengan signifikansi $(p)=0,384>0,05$ (homogen). Uji homogenitas skor gain ternormalisasi peningkatan kemampuan pembuktian matematik mahasiswa kelas eksperimen dan kelas kontrol sebesar 2,914 dengan signifikansi 0,096 (homogen). Hasil yang diperoleh menunjukkan bahwa ketiga data baik pretest, posttest, dan skor gain ternormalisasi sampel berasal dari populasi yang bervariansi sama (homogen).

\section{Uji Hipotesis}

Uji perbedaan rerata bertujuan untuk menguji hipotesis dalam membuktikan bahwa kemampuan awal mahasiswa mengenai kemampuan pembuktian matematik itu sama, maka dilakukan uji rerata dalam bentuk two tailed. Oleh karena data pretest kelas eksperimen dan kelas kontrol menunjukkan bahwa data berasal dari populasi yang tidak berdistribusi normal meski sampel berasal dari populasi yang memiliki variansi sama, maka pengujian hipotesis untuk membandingkan dua sampel independen dilakukan dengan menggunakan kaidah statistika nonparametrik, yaitu: uji Mann-Whitney dengan taraf signifikansi $5 \%$. Nilai $p$ value yang diperoleh dari uji MannWhitney adalah 0,12 . Nilai tersebut lebih dari 0,05, maka berdasarkan kriteria pengujian hipotesis, Ho diterima. Hal ini menunjukkan bahwa tidak terdapat perbedaan rerata skor pretes antara kelas eksperimen dan kelas kontrol. Dengan kata lain, kemampuan awal pembuktian matematik mahasiswa kelas eksperimen dan kelas kontrol adalah sama.

Pengujian hipotesis untuk membuktikan bahwa kemampuan pembuktian matematik mahasiswa setelah diberikan perlakuan mengalami perbedaan, maka dillakukan uji rerata dalam bentuk two tailed. Oleh karena data posttest kelas eksperimen dan kelas kontrol menunjukkan bahwa data berasal dari populasi yang tidak berdistribusi normal meski sampel berasal dari populasi yang memiliki variansi sama (homogen), maka pengujian hipotesis untuk 
membandingkan dua sampel independen dilakukan dengan menggunakan kaidah statistika nonparametrik, yaitu: uji Mann-Whitney dengan taraf signifikansi $5 \%$. Nilai $p$ value yang diperoleh dari uji MannWhitney adalah 0,028. Nilai tersebut kurang dari 0,05, maka berdasarkan kriteria pengujian hipotesis, Ho ditolak, yaitu terdapat perbedaan kemampuan pembuktian matematik mahasiswa antara kelas eksperimen dengan kelas kontrol.

Uji hipotesis untuk menjawab rumusan masalah yang kedua dilakukan untuk membuktikan bahwa terdapat peningkatan kemampuan pembuktian matemati mahasiswa pada kelas eksperimen secara signifikan dibandingkan dengan kelas kontrol. Uji hipotesis ini dilakukan dengan menggunakan data skor gain ternormalisasi kelas eksperimen dan kelas kontrol pada uji Mann-Whitney satu pihak, karena data berasal dari populasi yang tidak berdistribusi normal meski sampel berasal dari populasi yang memiliki variansi sama (homogen). Berdasarkan perhitungan uji perbedaan rerata dengan uji Mann-Whitney dua pihak diperoleh nilai signifikansi yaitu 0,011 . Untuk pengujian menggunakan uji hipotesis satu pihak, maka nilai $p$ value (sig.2-tailed) harus dibagi dua menjadi $\frac{0,011}{2}=0,0055$. Hasil tersebut menunjukkan bahwa $0,0055<0,05$ sehingga $\mathrm{H}_{0}$ ditolak. Artinya peningkatan kemampuan pembuktian matematik mahasiswa yang pembelajarannya menggunakan pembelajaran dengan metode Moore termodifikasi lebih baik secara signifikan daripada mahasiswa yang memperoleh konvensional.

\section{Pembahasan}

Berdasarkan analisis data di atas, menunjukkan bahwa antara pembelajaran dengan metode Moore termodifikasi dan pembelajaran konvensional sama-sama meningkatkan kemampuan pembuktian matematik mahsiswa dalam perkuliahan Struktur Aljabar. Meskipun begitu, peningkatan kemampuan pembuktian matematik mahasiswa yang mengikuti pembelajaran Struktur Aljabar dengan metode Moore termodifikasi lebih signifikan dan merata dibandingkan dengan mahasiswa yang mengikuti pembelajaran konvensional. Salah satu alasannya, pembelajaran dengan metode Moore terpusat kepada mahasiswa (student centered learning).

Pada proses pelaksanaan pembelajaran Struktur Aljabar dengan metode Moore, mahasiswa diminta bekerja secara mandiri dalam menyelesaikan Lembar Kegiatan Mahasiswa (LKM) yang didesain untuk mengembangkan kemampuan pembuktian matematik, yaitu dalam hal membaca bukti dan mengkonstruksi bukti. Dalam menyelesaikan LKM, mahasiswa berusaha mengonstruksi ide atau gagasannya menurut pengetahuannya sendiri berdasarkan definisi, teorema, atau lemma yang sudah dipelajari. Mahasiswa tidak diperkenankan membuka referensi atau buku teks, kecuali keadaan memaksa sekali. Meskipun begitu, nampak mahasiswa berusaha menyelesaikan LKM. Selain itu, mahasiswa tidak diperkenankan pula berkolaborasi bersama teman yang lain. Keadaan ini yang terkadang sulit dilakukan oleh mahasiswa, karena mahasiswa terbiasa menyelesaikan LKM dengan berkolaborasi dengan teman yang lain di luar pembelajaran dengan metode Moore termodifikasi. Pada keadaan ini diperlukan komitmen bersama antara 
mahasiswa dan dosen dalam melaksanakan kegiatan pembelajaran dengan metode ini. Oleh karena itu, dosen perlu menciptakan kondisi lingkungan belajar yang kondusif agar pembelajaran dengan metode ini dapat berlangsung dengan baik.

Setelah menyelesaikan LKM, perwakilan mahasiswa diminta untuk mempresentasikan hasilnya di depan kelas, baik secara lisan maupun tertulis. Ketika menyampaikan gagasannya berkaitan dengan membaca bukti dan mengonstruksi bukti suatu soal, mahasiswa berusaha mempertahankan gagasannya tersebut. Mahasiswa yang lain menanggapi mahasiswa yang presentasi tersebut. Sementara dosen hanya memfasilitasi dan mengarahkan diskusi kelas sehingga pembelajaran tetap berlangsung dengan baik. Kegiatan ini memungkinkan mahasiswa dapat bertukar ide atau gagasan berkaitan dengan konsep yang menjadi dasar dalam pembuktian. Kegiatan ini juga dapat mengidentifikasi mahasiswa apakah sudah memahami konsep dengan baik atau tidak, apakah mampu membuktikan suatu soal atau tidak. Dengan demikian, kegiatan ini memungkinkan dapat menguatkan pemahaman tentang konsep-konsep, lema, dan teorema yang telah dikuasai mahasiswa, sekaligus mengembangkan kemampuan pembuktian matematik mahasiswa.

Keberhasilan metode Moore termodifikasi dalam meningkatkan kemampuan pembuktian matematik mahasiswa dalam penelitian ini sejalan dengan pendapat Mahavier, May, dan Parker (2006) yang menyatakan bahwa metode Moore merupakan metode pedagogi yang efektif, dalam membangkitkan minat siswa untuk bertanya, bereksplorasi, menemukan (discover), dan mengembangkan matematika dengan kemampuannya sendiri. Hal ini juga didukung pendapat Maya dan Sumarmo (2011) yang menyatakan bahwa pembelajaran dengan metode Moore termodifikasi dapat menjadi salah satu alternatif pembelajaran untuk mendukung mahasiswa aktif dalam proses pembelajaran dengan belajar mandiri sehingga mahasiswa dapat mengkonstruksi bukti sendiri. Akibatnya, kemampuan pembuktian matematik mahasiswa semakin berkembang.

Hasil penelitian ini juga sejalan dengan penelitian Arnawa (2009) yang meneliti tentang kemampuan mahasiswa dalam memvalidasi bukti dalam perkuliahan Struktur Aljabar dengan menerapkan salah satu pembelajaran yang berpusat pada mahasiswa (student centered learning) yakni pembelajaran berdasarkan teori APOS. Kesimpulan yang diperoleh dalam penelitiannya bahwa mahasiswa yang memperoleh pembelajaran Struktur Aljabar berdasar teori APOS mempunyai kemampuan memvalidasi bukti lebih baik secara signifikan dibandingkan dengan mahasiswa yang memperoleh pembelajaran konvensional.

Berdasarkan ulasan tersebut, dapat diambil kesimpulan bahwa pembelajaran yang berpusat pada mahasiswa (student centered learning) dalam perkuliahan yang mengkaji permasalahan pembuktian dapat mengembangkan kemampuan pembuktian mahasiswa secara signifikan. Pembelajaran yang dimaksud antara lain pembelajaran dengan metode Moore (termodifikasi), pembelajaran berdasarkan teori APOS, atau pembelajaran yang berpusat pada mahasiswa lainnya. 


\section{KESIMPULAN DAN SARAN}

Berdasarkan hasil analisis dan pembahasan terhadap hasil penelitian di atas, dapat disimpulkan bahwa: 1) Secara umum, kemampuan pembuktian matematik mahasiswa yang mengikuti pembelajaran dengan metode Moore termodifikasi mempunyai rerata yang lebih baik secara signifikan daripada mahasiswa yang mengikuti pembelajaran konvensional dalam perkuliahan Struktur Aljabar. 2) Peningkatan kemampuan pembuktian matematik mahasiswa yang mengikuti pembelajaran dengan metode Moore termodifikasi lebih baik secara signifikan dan lebih merata daripada mahasiswa yang mengikuti pembelajaran konvensional dalam perkuliahan Struktur Aljabar.

Berdasarkan kesimpulan penelitian tersebut, dapat diberikan saran bahwa: 1) Pembelajaran yang menggunakan metode Moore termodifikasi dapat digunakan untuk mengembangkan kemampuan pembuktian matematik mahasiswa. Oleh karena itu, dosen dapat menggunakan pembelajaran ini sebagai salah satu alternatif dalam perkuliahan Struktur Aljabar. 2) Dosen dapat menggunakan pembelajaran yang berpusat pada mahasiswa (student centered learning) dalam perkuliahan, terutama pembelajaran yang menekankan pada permasalahan pembuktian, karena dapat mengembangkan ketrampilan berpikir matematik dan kemandirian belajar mahasiswa.

\section{DAFTAR PUSTAKA}

Arnawa, I.M., dkk. 2009. Pengembangan Perangkat Pembelajaran Berdasarkan Teori APOS untuk Meningkatkan Kualitas Perkuliahan Aljabar Abstrak. Artikel Ilmiah Penelitian
Hibah Bersaing, FMIPA Universitas Andalas Padang.

Arnawa, I.M. 2009. Mengembangkan Kemampuan Mahasiswa dalam Memvalidasi Bukti pada Aljabar Abstrak melalui Pembelajaran Berdasarkan Teori APOS. Jurnal Matematika dan Sains, Juni 2009, Vol. 14 No. 2.

Herlina, E. 2013. Meningkatkan Advanced Mathemathical Thinking Mahasiswa dengan Menggunakan Pendekatan APOS, Prosiding Seminar Nasional Matematika dan Pendidikan Matematika STKIP Siliwangi Bandung, Volume 1, Tahun 2013. ISSN 977-2338831, hal. 315-327.

Herlina, E. 2015. Meningkatkan Advanced Mathemathical Thinking Mahasiswa, Infinity, Jurnal Ilmiah Program Studi Matematika STKIP Siliwangi Bandung, Vol 4, No.1, Februari 2015.

Mahavier, W.T., May, E.L., \& Parker, G.E. 2006. A Quick-Start Guide To The Moore Method. [Online]. Tersedia: http://www.discovery.utexas.edu/r $\underline{\mathrm{lm} / \text { reference/quick_start-3.pdf [10 }}$ April 2015].

Maya, R. \& Sumarmo, U. 2009. Pengembangan Kemampuan Pembuktian Matematik Mahasiswa, dalam Seminar Matematika dan Pendidikan Matematika di Universitas Negeri Malang pada 28 Juni 2009.

Maya, R. \& Sumarmo, U. 2011. Mathematical Understanding and Proving Abilities: Experiment 
with Undergraduate Student by Using Modified Moore Learning Approach, Indoms. J.M.E Vol. 2 No. 2, July 2011, Pp. 231-250

Nurlaelah, E. 2009. Refleksi Mahasiswa terhadap Pembelajaran Mata Kuliah Struktur Aljabar 1 dengan Menggunakan Program ISETL. (Makalah). Diunduh: file.upi.edu/Direktori/FPMIPA/JU R._PEND.../MK-Elah_3.pd.

Saefudin, A.A. 2012. Pengembangan Kemampuan Berpikir Kreatif Siswa dalam Pembelajaran Matematika dengan Pendekatan Pendidikan Matematika Realistik Indonesia (PMRI). Jurnal AlBidāyah, Vol 4 No. 1, Juni 2012.

Sugiyono. 2011. Metode Penelitian Kuantitaif, Kualitatif, dan Kombinasi (Mixed Methods). Bandung: Alfabeta.

Suryana, A. 2012. Kemampuan Berpikir Matematis Tingkat Lanjut (Advanced Mathematical Thinking) dalam Mata Kuliah Statistika Matematika 1, Prosiding Seminar Nasional Matematika dan Pendidikan
Matematika dengan tema " Kontribusi Pendidikan Matematika dan Matematika dalam Membangun Karakter Guru dan Siswa" pada tanggal 10 November 2012 di Jurusan Pendidikan Matematika FMIPA UNY, ISBN : 978-979-16353-8-7, hal. MP 37-48.

Suryana, A. 2013. Penerapan Model Pembelajaran PACE dalam Meningkatkan Advanced Mathematical Thinking. Prosiding Seminar Nasional Matematika dan Pendidikan Matematika STKIP Siliwangi Bandung, Volume 1, Tahun 2013. ISSN 977-2338831, hal. 272-279.

Tall, D. 2002. Advanced Mathematical Thinking. Mathematics Education Library. Dordrecht: Kluwer Academic Publishers Group.

Yoo, S. 2008. Effects of Traditional and Problem Based Instruction on Conceptions of Proof and Pedagogy in Undergraduates and Prospective Mathematics Teacher, Dissertasion of The University Of Texas At Austin: Tidak

Dipublikasikan. 